\title{
A gravimetric study of the Pitangui greenstone belt in the Mateus Leme region - NW Quadrilátero Ferrífero, Brazil
}

Joana Reis Magalhães ${ }^{* 1}$, Caio Alencar de Matos ${ }^{1}$, Paulo Henrique Amorim Dias ${ }^{1},{ }^{1}$ Geological Survey of Brazil.

\section{Copyright 2021, SBGf - Sociedade Brasileira de Geofísica}

This paper was prepared for presentation during the $17^{\text {th }}$ International Congress of the Brazilian Geophysical Society held in Rio de Janeiro, Brazil, 16-19 August 2021.

Contents of this paper were reviewed by the Technical Committee of the $17^{\text {th }}$ International Congress of the Brazilian Geophysical Society and do not necessarily represent any position of the SBGf, its officers or members. Electronic reproduction or represent any position of the SBGf, its officers or members. Electronic reproduction or
storage of any part of this paper for commercial purposes without the written consent storage of any part of this paper for commercial
of the Brazilian Geophysical Society is prohibited.

\begin{abstract}
The Quadrilátero Ferrífero region (southeast Brazil) encompasses important Archean greenstone belt sequences. In this work we performed a $2 \mathrm{D}$ gravimetric modeling using the recently acquired terrestrial gravity data from a northeast region in the Quadrilátero Ferrífero, and correlate the anomalies with the known geological surface information and airbone geophysical data to evaluate models for the Pitangui greenstone belt. Although the Pitangui greenstone sequence has been mapped, its subsurface geometry is poorly known. Prominent gravity highs are observed in the profile center over the high density $\left(2930 \mathrm{~kg} / \mathrm{m}^{3}\right)$ metaultramafic magmatism. Units of mafic $\left(2900 \mathrm{~kg} / \mathrm{m}^{3}\right)$ and metasedimentary $\left(2930 \mathrm{~kg} / \mathrm{m}^{3}\right)$ rocks were also individualized. Gravity lows are associated with gneissic and granitic rocks, occurring at the edges of the crosssection $\left(\leqslant 2730 \mathrm{~kg} / \mathrm{m}^{3}\right)$. The data also suggests the presence of a non-mapped granitic intrusion that is coherent with the ternary image. The modelling indicates that this greenstone belt has limited depth around $2 \mathrm{~km}$, which is comparable to thicknesses obtained elsewhere from previous work.
\end{abstract}

\section{Introduction}

The use of gravimetric modeling has been applied to greenstone belts terranes in order to assist in the geological and tectonic knowledge of these sequences (e.g., De Beer 1982, Blum et al. 2000, Ranganai et al. 2008, Ramotoroko et al. 2016, Le Pape et al. 2017). Lateral changes of density produces local variations in the gravitational field value that can be detected, allowing estimations in the distribution of the subsurface densities. In general, the greenstone belts sequences are characterized by a high gravimetric region, due to the volume of mafic-ultramafic rocks, which are denser than the gneiss-granitic crustal material that hosts them. This property makes gravimetry a suitable technique to estimate greenstone belts geometry, thickness and, in some cases, the main subsurface structures.

In southeastern Brazil (Figure 1), important greenstone belt sequences occur in the Quadrilatero Ferrífero (QF; "Iron Quadrangle") region and its surroundings. The QF is an important metallogenic province (e.g., Lobato et al.
$2001 a, b$ and references therein) containing several worldclass iron and gold deposits, located at the southeastern border of the São Francisco craton (Figure 1).

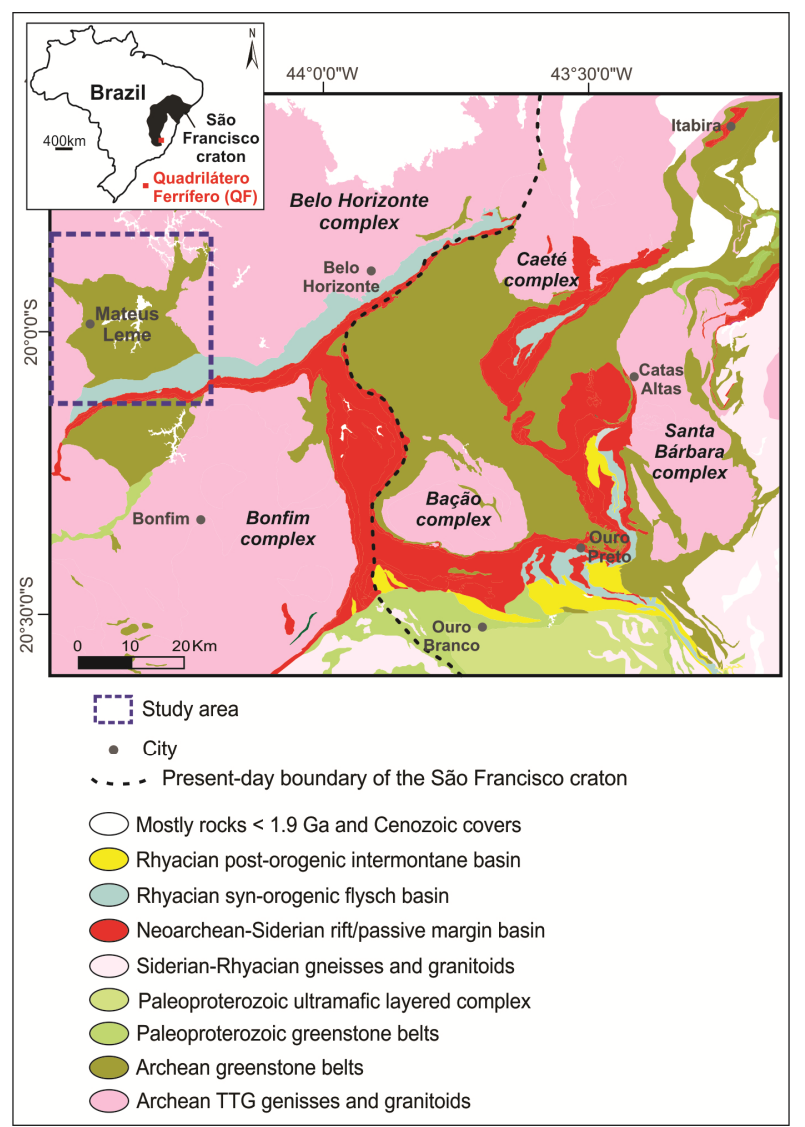

Figure 1 - Simplified geological map of the QF region highlighting the study area, and its location at the São Francisco craton southeastern border. Modified from Silva et al. (2020).

In order to investigate thickening, vertical and lateral geometry of a greenstone occurrence in the NW region of the Quadrilátero Ferrífero, this work presents a $2 \mathrm{D}$ modeling developed with terrestrial gravimetric data collected along a cross-section close to Mateus Leme municipality. The area was chosen due to the poor number of geological and geophysical studies. The obtained gravimetric anomalies were associated to airborne magnetic data, geological surface maps and density information. Finally, correlations between the models obtained by gravimetric interpretations and those suggested by surface geology were evaluated. The integration of the data also resulted in a geologicalgeophysical map of the modeled units (Figure 2). 


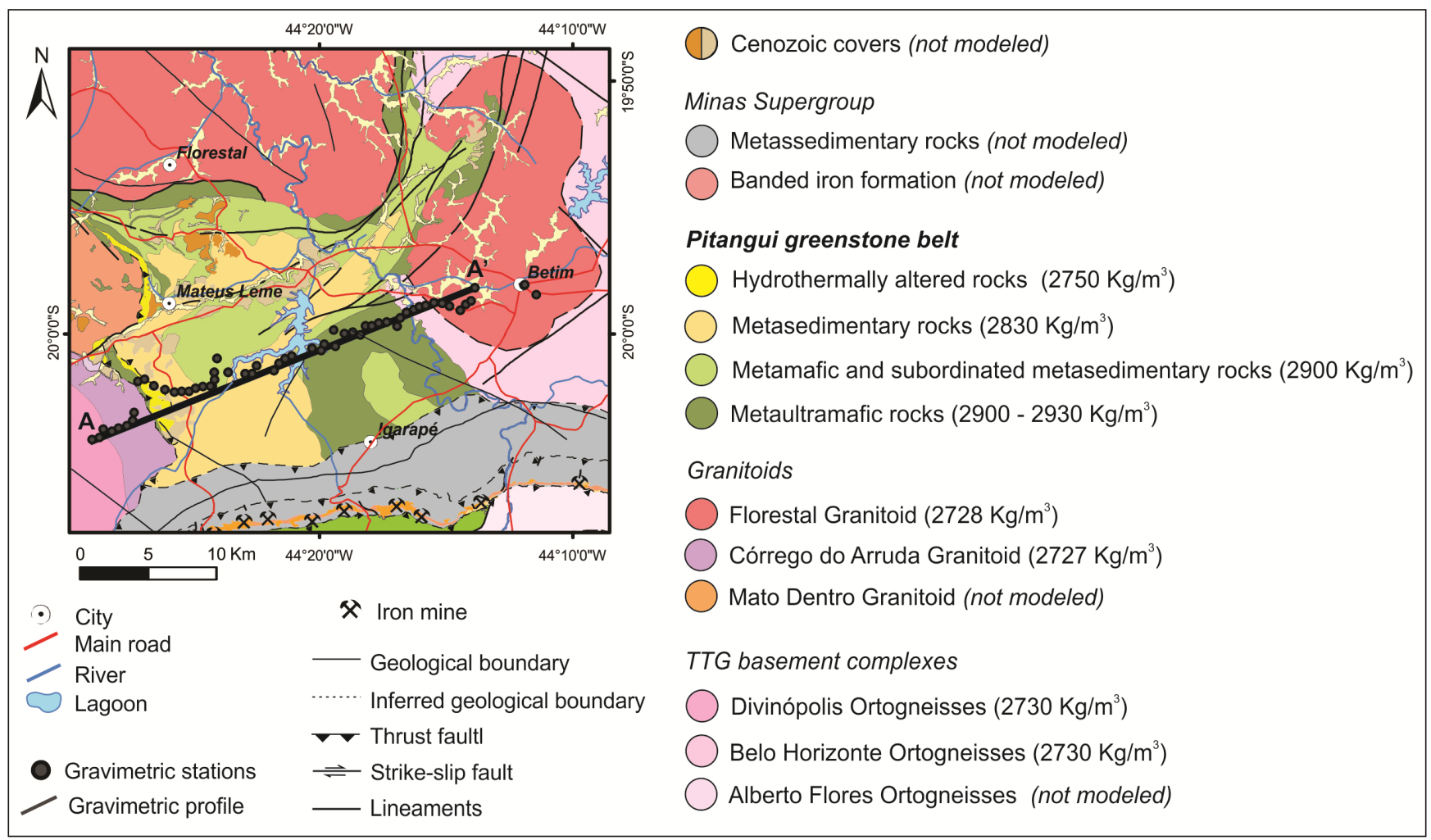

Figure 2 - Geological-geophysical map of the modeled units, with the location of the gravimetric cross-section (A-A'). Modified from Romano et al. (2009) and Ribeiro and Baltazar (2013).

\section{Method}

Terrestrial gravimetric stations were collected in a transversal cross-section to the main geological structures of interest. Its position was limited to the main roads of the area due to the irregular topography of the region.

The acquisition used the CG5 Autograv Gravity Meter (Scintrex) differential gravimeter and a pair of Hiper SR (Topcon) GPS. One GPS was fixed as a base, while the other was used in itinerant mode accompanying the gravimeter. The distance between the fixed and itinerant GPS did not exceed $40 \mathrm{~km}$. The GPS processing was performed following the steps: processing by precise point; data processing of base and itinerant GPS locations, using the Magnet Tools software; transformation of geometric height to orthometric height using the ellipsoid height correction in relation to the geoid in the MAPGEO2015 software (version 1.0).

The cross-section has WSW-ENE orientation and its extremities are defined by the coordinates: $554097 / 7780614$ and 580438/7791705 (UTM N/UTM E; Sirgas 2000 Datum - 23S Zone), respectively (Figure 2). The profile is $28.5 \mathrm{~km}$ long and consists of 61 gravimetric stations with preferential spacing of $0.5 \mathrm{~m}$, but reaching up to $2 \mathrm{~km}$. The stations were projected in the profile distant up to $3 \mathrm{~km}$.

The gravimetric data were processed using the Oasis Montaj software (Geosoft), following the procedures: tidal correction; gravimeter height correction; drift correction; absolute gravity calculation; normal gravity correction using the Geodetic Reference System formula (Moritz, 1980); free air correction; Bouguer correction with an average crust density of $2.67 \mathrm{~g} / \mathrm{cm}^{3}$; terrain correction with topography data from the National Oceanic and Atmospheric Administration (NOAA - GLOBE project); gridding by the kriging method, in which the cell size is determined by the equation: $1 / 4 \sqrt{ }$ ((Grid Area) / (Number data points)). The resulting cell size of the map was approximately $1 \mathrm{~km}$.

Before 2D modeling, the values of the Bouguer Anomaly regional map were removed over the points of the acquired stations. The 2D gravimetric modeling was performed using the GMSYS-2D module of the Oasis Montaj software (Geosoft), according to the calculation models of Talwani et al. (1959) and Talwani (1964).

Aerial geophysical surveys (CODEMG - Area 2) were used for delimitation of geological-geophysical domains in the gravimetric investigation (Figure 3 ). Density data of the modeled rocks were based on studies in nearby locations (Matos 2019). Surface geology information was extracted from 1:100,000 scale geological maps available in the region (Romano et al. 2009, Ribeiro and Baltazar 2013) and a $1: 75,000$ scale map in the adjacent region (Marinho et al. 2019). Based on these maps, the crosssection covers the following geological units: i) TTG orthogneisses of the Belo Horizonte and Divinópolis complexes, representing the Archean basement; ii) metavolcano-sedimentary sequence of the Pitangui greenstone belt; and iii) cenozoic covers (Figure 2). 


\section{Results}

Figure 3A shows the Bouguer anomaly map for the study region. The gravimetric profile cover a transition region between a gravimetric high in the central portion, showing anomalies of ca. $-75 \mathrm{mGal}$, and areas of low gravimetric values in the west and east, with Bouguer anomalies of ca. $-96 \mathrm{mGal}$ and $-93 \mathrm{mGal}$, respectively.

The greenstone belt sequence corresponds to the high gravimetric area, with limits around $-89 \mathrm{mGal}$ to $-94 \mathrm{mGal}$. The TTG basement is compatible with areas showing the lowest Bouguer anomaly values. The image of the Analytical Signal Amplitude map (ASA; Figure 3B) highlights the contrasts between these different geological units, individualizing the greenstone sequence, which displays values between 0.020 and $0.226 \mathrm{nT} / \mathrm{m}$.

Figure 4 shows the results of the gravimetric modeling. According to the geological maps, the TTG basement orthogneisses are individualized in two units modeled with the same density $\left(2730 \mathrm{Kg} / \mathrm{m}^{3}\right)$ : i) Belo Horizonte Complex, which occurs in the central-east region of the profile and hots the greenstone sequence; and ii) Divinópolis Complex, restricted to the west region of the cross-section.

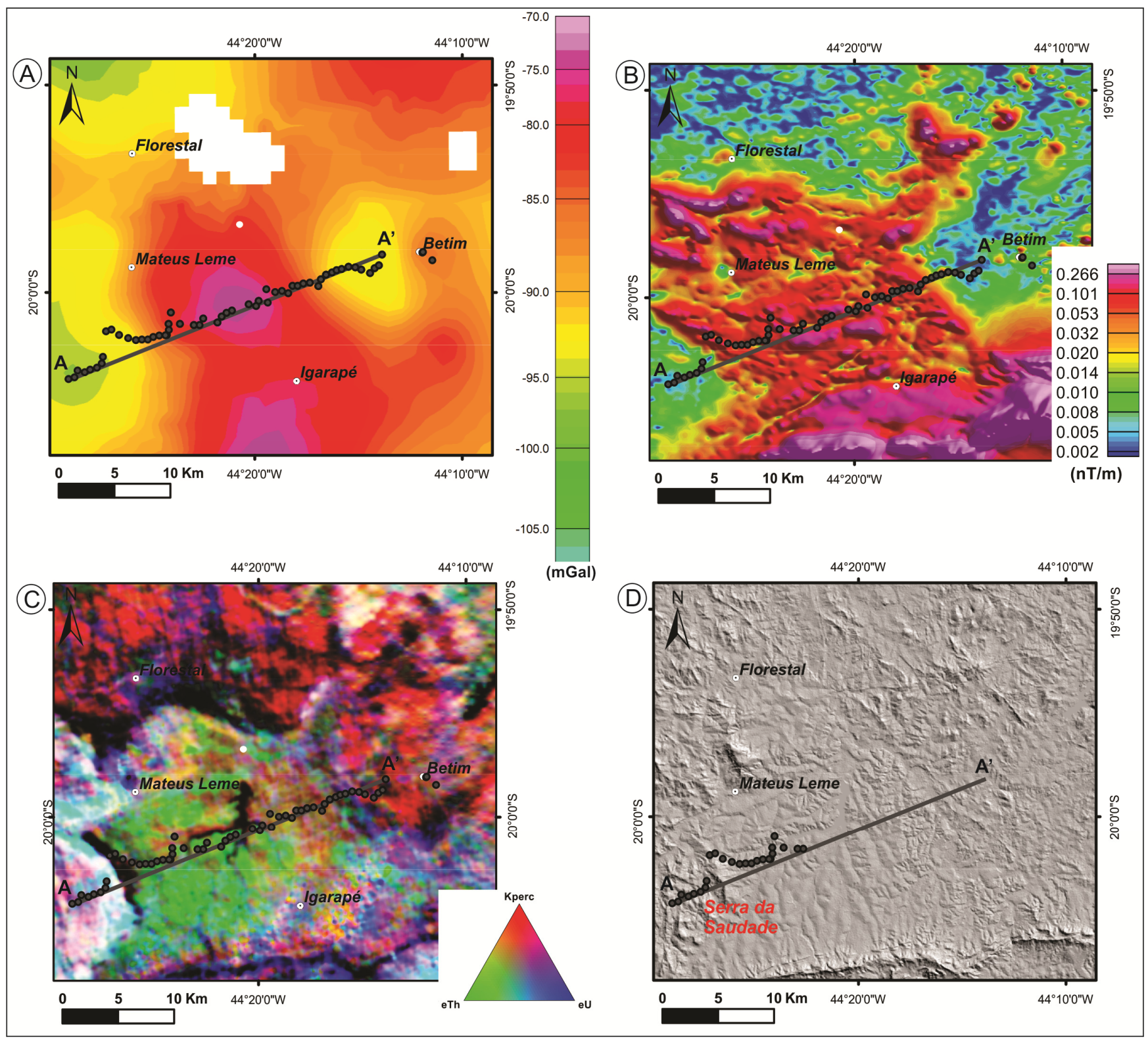

Figure 3 - A) Bouguer anomaly map; B) Analytical Signal Amplitude image ; C) Gamma-spectrometry image of the RGB ternary composition; and D) Shuttle Radar Topography Mission (SRTM) image, with the gravimetric cross-section location (A$\left.A^{\prime}\right)$. 
The greenstone belt sequence comprises metaultramafic rocks at its basal section $\left(2930 \mathrm{Kg} / \mathrm{m}^{3}\right)$, such as serpentinites and talc-chlorite schists; which is covered by an association of metamafic and subordinate metasedimentary rocks $\left(2900 \mathrm{Kg} / \mathrm{m}^{3}\right)$, including metabasalts, iron formation and quartz-mica schist varieties; which in turn is overlapped by metasedimentary rocks, representing the greenstone upper section (2830 $\mathrm{Kg} / \mathrm{m}^{3}$ ) (Figure 2; 4A).

The modeled gravimetric profile suggests a relatively symmetrical geometry for the greenstone, reaching $2 \mathrm{~km}$ deep in the central portion. The modeling reveals a thick unit of metaultramafic rocks at the greenstone base, narrowing towards the west (Figure 4). The amplitude of the Bouguer anomaly for the greenstone is approximately +13 mGal.

A small and symmetric keel at east was modeled in accordance with geological cartography and gravimetric data. It is a branch of the main keel, reaching a depth of around $200 \mathrm{~m}$.

Hydrothermally altered rocks occur in the Serra da Saudade region (Figure 3D; 4B), juxtaposed by thrust faults in the western sector of the cross-section, were grouped and modeled with a density of $2750 \mathrm{Kg} / \mathrm{m}^{3}$ (Figure 4). However, in the geological profile (Figure 4B), the lithotypes were individualized characterized by distinct hydrothermal alteration zones.

The greenstone contact to the west is marked by a thrust fault that places this sequence over the Córrego do Arruda granitoid $\left(2727 \mathrm{Kg} / \mathrm{m}^{3}\right.$, Figure 2; 4). This contact is identified by a mild break in the Bouguer anomaly pattern to the west of Serra da Saudade (Figure 3A).

Finally, the east edge of the cross-section suggests the presence of a granitic pluton of $2728 \mathrm{Kg} / \mathrm{m}^{3}$. Its occurrence was based on the ternary image (RGB composition; Figure $3 \mathrm{C}$ ) of $\mathrm{K}$, eTh, and eU. This pluton is probably associated with the Florestal batholith magmatism, which occurs at the northern limit of the greenstone (Figure 2).

\section{Conclusions}

A gravimetric model based on the local geology allowed the elaboration of a vertical section with the probable geology of the greenstone belt.

The metavolcano-sedimentary sequence that outcrops in the NW region of the Quadrilátero Ferrífero was correlated to the Pitangui greenstone belt, due to the geological continuity (Marinho et al. 2019). The results of $2 \mathrm{D}$ gravimetric modeling suggest that the geometry of the greenstone keel in the Mateus Leme region is symmetrical and reaches depths around $2 \mathrm{~km}$, similar to what was presented by Matos (2019) for some localities of the Pitangui sequence to the west of the study area.

Furthermore, the gravimetric model of the Mateus Leme profile, in agreement with the airbone geophysical images, suggests a non-mapped intrusive granitic body in the Belo Horizonte Complex, which must be verified in field work. The data from gravimetric stations to the east of the profile (Betim city, Figure 2) continue to show variations in the Bouguer anomalies, which may be related to other non-mapped lithological domains or heterogeneities in the TTG basement complexes.

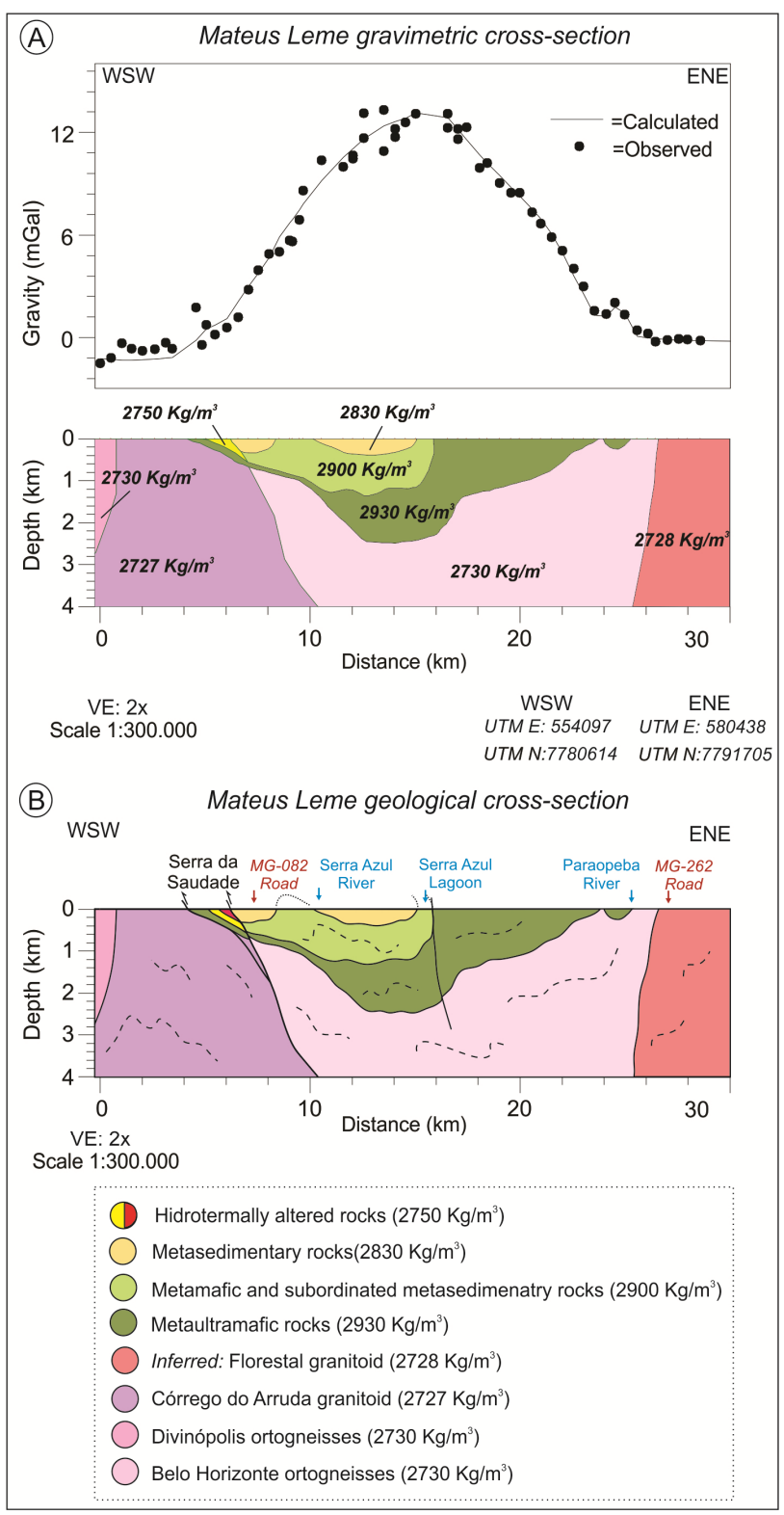

Figure 4 - A) WSW-ENE Mateus Leme gravimetric profile with the modeled curve; $B$ ) interpreted geological cross-section showing the possible geometric relations between the greenstone belt keel and the TTG basement.

\section{Acknowledgments}

The authors would like to thank the Geological Survey of Brazil (CPRM) for the data and support.

\section{References}

DE BEER, J. 1982. A geophysical study of the Murchison greenstone belt, South Africa, Revista Brasileira de Geociências, 12(1-3), 105-112. 
BLUM, M. D. L. B., PIRES, A. C. B., MORAES, R. A. V. 2017. Gravity inversion on granite-greenstone belt areas: Crixás, Guarinos and Pilar de Golás, Brazil. Revista Brasileira de Geociências, 30(3), 547-550.

LE PAPE, F., JONES, A.G., JESSELL, M.W., PERROUTY, S., GALLARDO, L.A., BARATOUX, L., HOGG, C., SIEBENALLER, L., TOURÉ, A., OUIYA, P., BOREN, G. 2017. Crustal structure of southern Burkina Faso inferred from magnetotelluric, gravity and magnetic data. Precambrian Research, 300, 261-272.

LOBATO L. M., RIBEIRO-RODRIGUES L. C., VIEIRA F. W. R. 2001b. Brazil's premier gold province. Part II: geology and genesis of gold deposits in the Archean Rio das Velhas greenstone belt, Quadrilátero Ferrífero. Mineralium Deposita, 36, 249-277

LOBATO L. M., RIBEIRO-RODRIGUES L. C., ZUCCHETTI M., NOCE C.M., BALTAZAR O. F., SILVA L. C., PINTO C. P. 2001a. Brazil's premier gold province. Part I: The tectonic, magmatic, and structural setting of the Archean Rio das Velhas greenstone belt, Quadrilátero Ferrífero. Mineralium Deposita, 36, 228-248.

MARINHO, M. D. S., SILVA, M. A. D. S., LOMBELLO, J. C., DI SALVIO, L. P. P., SILVA, R. N., FÉBOLI, W. L., BRITO, D. C. 2019. Mapa geológico e de recursos minerais integrado: área de relevante interesse mineral, ARIM, Quadrilátero Ferrífero, subárea faixa Pará de Minas-Pitangui. Companhia de Pesquisa de Recursos Minerais-CPRM. Available on line at: http://rigeo.cprm.gov.br/jspui/handle/doc/19393

MATOS, C. A. D. 2019. Modelagem e inversão de métodos potenciais do terreno granito-greenstone Rio das Velhas no Noroeste do Quadrilátero Ferrífero. MSc. dissertation, Universidade de São Paulo, São Paulo, Brazil.

MORITZ, H. 1980. Advanced physical geodesy. Advances in Planetary Geology.

RAMOTOROKO, C. D., RANGANAI, R. T., NYABEZE, P. 2016. Extension of the Archaean Madibe-Kraaipan granite-greenstone terrane in southeast Botswana: Constraints from gravity and magnetic data. Journal of African Earth Sciences, 123, 39-56.

RANGANAI, R. T., WHALER, K. A., EBINGER, C. J. 2008. Gravity anomaly patterns in the south-central Zimbabwe Archaean craton and their geological interpretation. Journal of African Earth Sciences, 51(5), 257-276.

RIBEIRO, L. M. D. A. L., \& BALTAZAR, O. F. 2013. Carta geológica: folha Igarapé, SF.23-X-A-II. Escala 1:100.000. Companhia de Pesquisa de Recursos Minerais-CPRM. Belo Horizonte, Minas Gerais, Brazil. Available at: http://rigeo.cprm.gov.br/jspui/handle/doc/17739

ROMANO, A. W, ARAÚJO, J. C. S., CARVALHO, H. R. S., OLIVEIRA, J. A., LEMOS, M. G., KNAUER, L. G., PAIVA, C. T. P., HEINECK, C. A. 2009. Carta geológica: folha Contagem, SF.23-Z-C-V. Escala 1:100.000. Programa Geologia do Brasil. Contrato Companhia de Pesquisa de Recursos Minerais - Universidade Federal de Minas Gerais. Belo Horizonte, Minas Gerais, Brazil.
SIlVA, M. A., PINTO, C. P., PINHEIRO, M. A. P., MARINHO, M. S., LOMBELLO, J. C., PINHO, J. M. M. P., GOULART, L. E. A.; MAGALHÃES, J. R. 2020. Mapa Geológico do Estado de Minas Gerais. Escala 1:1.000.000. Projeto Geologia do Estado de Minas Gerais. CPRM. Available on line at: http://rigeo.cprm.gov.br/jspui/handle/doc/21828

TALWANI, M. 1965. Computation with the help of a digital computer of magnetic anomalies caused by bodies of arbitrary shape. Geophysics, 30(5), 797-817.

TALWANI, M., WORZEL, J. L., LANDISMAN, M. 1959. Rapid gravity computations for two-dimensional bodies with application to the Mendocino submarine fracture zone. Journal of geophysical research, 64(1), 49-59. 